montal research of immense importanco, both economically and in medical terms, is that of nouro-endocrinology. At a more 'practical' level, the congress agreed that "It is important that research be continued on the factors affecting sex determination because of its economic importance", and went on to define means of expressing farm animal fortility in uniform torms so as to facilitate comparison of records, and to make recommendations concorning hygiene and legislation in animal hoalth.

\section{Research in Immunology}

Research in Immunology (WHO Technical Report Series No. 286) should interest evoryone who is concerned with this field of investigation, which is nowadays advanc. ing so rapidly and extending its influence in many directions. The Report deals with immunological problems under the following headings: I, immunoprophylaxis and immunotherapy; II, immunopathology; III, tissue antigens and transplantation; IV, immunochomistry; $V$, research programme in immunology. Each section comprises the report of a scientific group convened by the Director-General of the World Health Organization. Two annexes summarize the recommendations made for research and give an outline of current problems in immunology. The Report is obtainable in the United Kingdom from H.M. Stationery Office, the price being 8s. $6 d$., and it is also published in French and Spanish.

\section{CIBA Fellowships}

Several fellowships will be awarded for tenure during the academic year 1965-66 at continental universities or institutions for full-time research in chemistry, physics or some other allied scientific subject. They will be awarded to graduates of universities situated in the United Kingdom of Great Britain or Northorn Ireland or in the Republic of Iroland, or to mombers of those universitios graduating in 1961. It is anticipatod that some fellowships will be awarded to recent graduates and other followships to candidates who havo already taken their Ph.D. degree, or who have already spent somo time in industry. Tho basic award for Fellows who have already undorgone training in research and wish to continue post-doctorato studies will bo $£ 1,000$ por annum. For candidatos who have obtained a first degreo in science and wish to undergo training in research, the basic award will be $£ 700$ por annum. Awards may bo increased by appropriate additional allowances depending on place of study and marital status, etc. The total value of each fellowship will bo determined by the Advisory Panel. The amount awarded will be sufficient to cover the Fellow's full living and othor expenses (including all fees and cost of travel) during the tonure of his fellowship, which will be for one year, renewable for a further one or two years. Twelve CIBA Fellows are at present working at Aarhus, Brussels, Copenhagon, Geneva, Genoa, Heidelberg. Munich, Stockholm, Strasbourg and Zurich.

\section{University News:}

Birmingham

THE following appointments have been announced: Lecturer, Dr. N. Baggett (chomistry); Mrs. Christine A. McCauley (computing in the Department of Mathematical Physics). Research Fellows, C. Ashley (Imperial Chemical Industries Research Fellow in tho Departmont of Mechanical Engineering); Dr. T. L. Dillamore (Imperial Chemical Industries Rosearch Fellow in the Department of Physical Motallurgy); Dr. Toh-Hsing Wei (statistics in tho Departmont of Pure Mathematics).

Bristol

The following have beon electod to professorships: Dr. A. D. Buckingham (theoretical chemistry); G. F. C. Rogers (engineoring thermodynamics); Prof. A. R. Battorsby (organic chomistry). Announced also are the following appointments to lectureships: Dr. K. H. G.
Ashbee (metallurgy and coramics, within the Department of Physics); M. Chisholm (geography); Dr. K. B. Linton (medical bacteriology); Dr. S. Moran (pure mathematies); N. F. Richards (civil engineering); Dr. R. A. Sawyer (aeronautical engineering).

\section{Edinburgh}

THE following appointments have boon announced: Senior Lecturers, Dr. D. W. Moss (clinical chomistry); Dr. D. C. Simpson (medical physics); Dr. J. M. Last (public health and social medicine). Lecturers, Dr. E. M. Dixon (astronomy); Dr. J. S. McKinley McKe日 (biochomistry); Dr. Winifred L. Stafford (biochemistry); Dr. J. F. Collins (biophysics); P. Edmond (clinical surgory); H. Whitfield (computor unit); E. W. Powell (dermatology); A. M. Nicolson (eloctrical engineoring); Dr. D. C. S. Hutchison (medicine); Dr. N. M. B. Dean (public health and social medicine); G. K. Crompton (respiratory disoases and tuberculosis); W. L. Ford (therapoutics).

Southampton

THE following appointments have been mado: Dr. R. L. Bell, reader in physical metallurgy in the University of London, to the chair of engineering matorials in the Department of Mechanical Engineering from a date to bo arranged. Dr. L. Brent of the National Institute for Medical Research, to the chair of zoology from April 20. Dr. W. A. Gambling, reader in electronies in the University, to the second chair of electronics. Dr. G. B. Trasler, lecturer in the Department of Sociology and Social Studies in tho University, to the chair of psychology.

\section{Synthesis of Organosilicon Monomers}

IT has been brought to tho Editor's attention that a British edition of this book (revicwed in Nature, 204, 512,1961 ) is published by Heywood Books (Temple Press Books, Ltd., London, W.C.1) to whom orders should be addressed by purchasers in the United Kingdom, the Commonwealth (excluding Canada) and Europe. 'The price is $130 s$.

\section{Announcements}

Mr. D. B. Colletr, a director of Dunlop Rubber Co., Ltd., has accepted the invitation to deliver the twontieth Foundation Lecturo of the Institution of the Rubber Industry. This will take place at the Midland Institute, Birmingham, on May 19, 1965.

A Meeting on "Plant Waxes, Cutin and Associated Compounds", organized by the Phytochemical Group, will be held in London on January 7. Further information can be obtained from A. H. Williams, Research Station, Long Ashton, Bristol.

A symposium on "Energy Transfer in Radiation Processes", arranged by tho Association for Radiation Research, will be held in University College, Cardiff, during January 7-9. Further information can be obtained from Dr. G. O. Phillips, Department of Chemistry, University College, Cardiff.

The 1965 Gordon Research Conferences on "Electrochemistry: Electrode Processes", "Polymers" and "Basic Chemistry of Aging" will bo held in Santa Barbara, California, during January 25-February 5. Further information can bo obtained from the director of the conferences, Dr. W. Goorge Parks, University of Rhode Island, Kingston, R.I.

A JoINT mooting of the North of England Section and the Spocial Techniques Group of the Society for Analytical Chemistry will be held in Leeds on December Il. A paper on "Some Aspects of Polarography" will be presented by M. L. Richardson. Further information can be obtained from the Society for Analytical Chemistry, 14 Belgrave Square, London, S.W.l. 